\title{
The osmoprotectant glycine betaine inhibits salt-induced cross-tolerance towards lethal treatment in Enterococcus faecalis
}

\author{
Vianney Pichereau, ${ }^{1}$ Stéphane Bourot, ${ }^{1}$ Sigrid Flahaut, ${ }^{2}+$ Carlos Blanco, ${ }^{1}$ \\ Yanick Auffray ${ }^{2}$ and Théophile Bernard ${ }^{1}$
} Author for correspondence: Vianney Pichereau. Tel: +332992861 41. Fax: +33299286140.
e-mail: vpichere@univ-rennes1.fr

1 UPRES-A CNRS 6026, Département Membranes \& Osmorégulation, Université de Rennes I, Campus de Beaulieu, 35042 Rennes, France

2 Laboratoire de Microbiologie de l'Environnement, Université de Caen, 14032 Caen, France
The response of Enterococcus faecalis ATCC 19433 to salt stress has been characterized previously in complex media. In this report, it has been demonstrated that this bacterium actively accumulates the osmoprotectant glycine betaine (GB) from salt-enriched complex medium BHI. To further understand the specific effects of GB and other osmoprotective compounds in salt adaptation and salt-induced cross-tolerance to lethal challenges, a chemically defined medium lacking putative osmoprotectants was used. In this medium, bacterial growth was significantly reduced by increasing concentrations of $\mathrm{NaCl}$. At $0.75 \mathrm{M} \mathrm{NaCl}, 90 \%$ inhibition of the growth rate was observed; GB and its structural analogues restored growth to the non-saltstressed level. In contrast, proline, pipecolate and ectoine did not allow growth recovery of stressed cells. Kinetic studies showed that the uptake of betaines shows strong structural specificity and occurs through a salt-stressinducible high-affinity porter $\left[K_{m}=3.3 \mu \mathrm{M} ; V_{\max }=130 \mathrm{nmol} \mathrm{min}-1\right.$ ( $\mathrm{mg}$ protein) ${ }^{-1}$; the uptake activity increased 400 -fold in the presence of $0.5 \mathrm{M}$ $\mathrm{NaCl}]$. Moreover, GB and its analogues were accumulated as non-metabolizable cytosolic osmolytes and reached intracellular levels ranging from 1.3 to $1.5 \mu \mathrm{mol}$ (mg protein) ${ }^{-1}$. In contrast to the beneficial effect of GB on the growth of salt-stressed cultures of $E$. faecalis, its accumulation inhibits the salt-induced cross-tolerance to a heterologous lethal challenge. Indeed, pretreatment of bacterial cells with $0.5 \mathrm{M} \mathrm{NaCl}$ induced resistance to $0.3 \%$ bile salts (survival of adapted cells increased by a factor of 6800 ). The presence of $G B$ in the adaptation medium reduced the acquisition of bile salts resistance 680-fold. The synthesis of 11 of the 13 proteins induced during salt adaptation was significantly reduced in the presence of GB. These results raise questions about the actual beneficial effect of GB in natural environments where bacteria are often subjected to various stresses.

Keywords: salt stress, stress protein synthesis, betaine analogues, osmoregulation, methylated onium compounds

\section{INTRODUCTION}

Most micro-organisms have to cope with a range of

tPresent address: Laboratoire de Biologie Cellulaire et Moléculaire, Université du Littoral-Côte d'Opale, 17 Avenue Blériot, BP699, 62228 Calais, France.

Abbreviations: AsB, arsenobetaine; $B \mathrm{~B}, \gamma$-butyrobetaine; $\mathrm{BHI}$, brain heart infusion; DM, defined medium; DMG, dimethylglycine; DMSA, dimethylsulfonioacetate; DMSP, dimethylsulfoniopropionate; GB, glycine betaine; MOC, methylated onium compound. abiotic stresses caused by fluctuations in their surroundings. Bacterial cells have developed powerful strategies to proliferate and survive under stressful conditions. Because the osmolarity of the environmental medium is one of the most variable parameters, much attention has been paid in recent years to understanding the mechanisms of bacterial adaptation to increased osmolarity.

One of the most powerful adaptive strategies bacterial cells have evolved to counteract low water activities of 
their growth media is the accumulation to high intracellular levels of a set of organic solutes that are synthesized de novo or actively taken up from the growth medium (Csonka \& Hanson, 1991; Gutierrez et al., 1995; Csonka \& Epstein, 1996). The exogenous osmoprotectants belong to a few classes of organic compounds that are neutral at physiological $\mathrm{pH}$ and compatible with cellular functions (Brown, 1976). They include imino acids (e.g. proline, ectoine, pipecolate) (Gouesbet et al., 1994; Jebbar et al., 1992, 1997) and amino acid derivatives such as betaines (e.g. glycine betaine, proline betaine, carnitine) or other methylated onium compounds (MOCs, e.g. the sulfonio and arsonio analogues of glycine betaine) (Le Rudulier et al., 1984; Lucht \& Bremer, 1994; Pichereau et al., 1997). Such compounds occur widely in food and natural environments, where they may protect bacterial cells against the deleterious effects of lowered water activity (Anthoni et al., 1991; Kets et al., 1994; Smith, 1996). In particular, glycine betaine (GB) displays a variety of beneficial physiological effects for salt-stressed cells (Csonka \& Epstein, 1996).

Concomitant with the accumulation of osmoprotectants, salt-stressed bacteria may change their program of gene expression, which is revealed by the induction of stress protein synthesis. Some of these proteins are known to be implicated in osmoadaptation in diverse bacteria. The most studied are the enzymes involved in osmolyte biosynthesis and the membrane osmoporters (Csonka \& Hanson, 1991; Lucht \& Bremer, 1994; Csonka \& Epstein, 1996). Among $\mathrm{NaCl}$ stress proteins, some polypeptides are induced by several stimuli and are usually called general stress proteins (Hecker et al., 1988; Hecker \& Völker, 1990; Völker et al., 1992; Flahaut et al., 1996).

Enterococcus faecalis is a ubiquitous Gram-positive bacterium resident of the human and animal gut. It can also survive in marine or fresh water and in various food products with different water activities (Flahaut $e t$ al., 1997; Godfree et al., 1997). A few studies have reported the accumulation of osmoprotectants in enterococci $(\gamma$ aminobutyric acid, potassium ions and GB) under high osmolarity conditions (Measures, 1975; Kunin \& Rudy, 1991 ; Peddie et al., 1996). Hyperosmotic shock increases the maximal temperature at which E. faecalis and other food-poisoning bacteria can grow (Tesone et al., 1981) and the bacterial resistance to thermal challenge (Flahaut et al., 1996). Osmotic upshock also induces high salt resistance and cross-protection against lethal treatments due to bile salts and ethanol (Flahaut et al., 1996). These induced tolerances are accompanied by increased synthesis of stress proteins in complex media (Flahaut et al., 1996).

To our knowledge, only preliminary studies have been devoted to the understanding of the mechanism of osmoregulation in E. faecalis. Moreover, limited attention has been focused on alterations in gene expression in response to osmotic stress with specific osmoprotectants. As polyauxotrophy is one of the physiological traits of E. faecalis, bacterial cultures were grown in complex media. Unfortunately, these media may contain high amounts of osmoprotective compounds that can influence bacterial osmotolerance (Kets et al., 1994; Amezaga et al., 1995). In this paper, we report on the behaviour of $E$. faecalis ATCC 19433 in complex and defined media under hypersaline conditions. We have characterized the uptake of several osmoprotectants and their efficiency in growth recovery. In addition, the influence of the most effective osmoprotectant, GB, was studied on both salt-induced crossprotection and stress protein synthesis.

\section{METHODS}

Bacterial strain and growth conditions. E. faecalis ATCC 19433 was used in this study. Cells were grown at $37^{\circ} \mathrm{C}$ without shaking in brain heart infusion (BHI, Difco) or in chemically defined medium (DM) adapted from Kets $e t$ al. (1994). DM contained (per litre deionized water) 5 g glucose, $2 \mathrm{~g} \mathrm{NH}_{4} \mathrm{Cl}, 6.8 \mathrm{~g} \mathrm{KH}_{2} \mathrm{PO}_{4}, 1 \mathrm{~g}$ sodium acetate, $0.6 \mathrm{~g}$ sodium citrate. $\mathrm{H}_{2} \mathrm{O}, 0.2 \mathrm{~g} \mathrm{MgSO}_{4} .7 \mathrm{H}_{2} \mathrm{O}, 50 \mathrm{mg} \mathrm{MnSO}_{4} . \mathrm{H}_{2} \mathrm{O}$, $10 \mathrm{mg} \mathrm{H}_{3} \mathrm{BO}_{3}, 1 \mathrm{mg} \mathrm{FeCl}_{3} .6 \mathrm{H}_{2} \mathrm{O}, 1 \mathrm{mg} \mathrm{ZnSO}_{4} .7 \mathrm{H}_{2} \mathrm{O}$, $0.5 \mathrm{mg} \mathrm{CuSO}_{4} .5 \mathrm{H}_{2} \mathrm{O}, 0.5 \mathrm{mg} \quad \mathrm{MnCl}_{2} .4 \mathrm{H}_{2} \mathrm{O}, 0.1 \mathrm{mg}$ $\mathrm{Na}_{2} \mathrm{MoO}_{4} \cdot 2 \mathrm{H}_{2} \mathrm{O}, 1 \mathrm{mg} \mathrm{CoCl} 2.6 \mathrm{H}_{2} \mathrm{O}, 0 \cdot 1 \mathrm{mg} \mathrm{NiCl} 2 \cdot 6 \mathrm{H}_{2} \mathrm{O}$. Amino acids were supplied at the following concentrations $\left(1^{-1}\right): 300 \mathrm{mg}$ L-cysteine, $200 \mathrm{mg}$ DL-methionine and DL-valine and $100 \mathrm{mg}$ each of $\mathrm{L}$-alanine, $\mathrm{L}$-asparagine, $\mathrm{L}$-aspartic acid, $\mathrm{L}$ glutamic acid, glycine, L-isoleucine, L-leucine, L-lysine- $\mathrm{HCl}, \mathrm{L}-$ threonine, L-tryptophan, L-tyrosine, L-arginine- $\mathrm{HCl}$, L-histidine, L-phenylalanine and L-serine. Ten milligrams each of the bases adenine, guanine and uracil was also added. The medium was supplemented with $5 \mathrm{ml} \mathrm{l}^{-1}$ of the solution of vitamins described by Kets $e t$ al. (1994). Glucose, amino acids and vitamin solutions were filter-sterilized $(0.45 \mu \mathrm{m}$, Millipore) separately. The osmolarity of the medium was increased by addition of $\mathrm{NaCl}$; the $\mathrm{pH}$ of the culture media was adjusted to 7 with $\mathrm{NaOH}$. Growth was monitored by measuring $\mathrm{OD}_{570}$. Protein contents were determined according to the Lowry method using bovine serum albumin as standard. When necessary, osmoprotectants were added to DM at a final concentration of $1 \mathrm{mM}$.

Extraction of intracellular solutes. E. faecalis was grown in $\mathrm{DM}$ or $\mathrm{BHI}$ to an $\mathrm{OD}_{570}$ of 0.6 . Cells were harvested by centrifugation and washed with a solution iso-osmotic with the corresponding culture medium. The pellet was extracted at least twice with $80 \%(\mathrm{v} / \mathrm{v})$ ethanol with vigorous stirring at room temperature for $30 \mathrm{~min}$. After centrifugation $(6500 \mathrm{~g}$, $10 \mathrm{~min}$ ), the supernatants (constituting the ethanol-soluble fraction, ESF) were pooled, evaporated to dryness at $40^{\circ} \mathrm{C}$ and dissolved in distilled water. The ethanol-insoluble pellets (ethanol-insoluble fraction, EIF) contained the intracellular macromolecular components and cellular envelopes. The efficiency of this technique was quantified by comparing the radioactivity recovered both in the ESF and the EIF, after extraction of cells supplied with $\left[{ }^{14} \mathrm{C}\right] \mathrm{GB}$, a non-catabolized molecule (see Results and Discussion). According to this technique, at least 90 and $97 \%$ of the intracellular labelled GB was extracted during the first and the second step of extraction, respectively.

Analysis of organic solutes. The organic solutes in the ESF were separated by two-dimensional paper chromatography in the solvents $n$-butanol/acetic acid/water (12:3:5, by vol.) and phenol $(80 \%, \mathrm{w} / \mathrm{v}$, in water $) /$ ammonia $(200: 1, \mathrm{v} / \mathrm{v})$ and/or 
by high-voltage paper electrophoresis according to Bernard $e t$ al. (1986). For the ${ }^{13} \mathrm{C}-\mathrm{NMR}$ spectral analysis of intracellular osmolytes, the ESF was evaporated to dryness and the dry residue was dissolved in $0 \cdot 6 \mathrm{ml} \mathrm{D}_{2} \mathrm{O}$. Natural-abundance ${ }^{13} \mathrm{C}$ NMR spectra were recorded in the pulsed Fourier transform mode at an operational frequency of $75.4 \mathrm{MHz}$ as described previously (Pichereau et al., 1998).

Chemicals and radiochemicals. All of the commercial chemicals were purchased from Sigma. Dimethylsulfonioacetate (DMSA), dimethylsulfoniopropionate (DMSP) and arsenobetaine (AsB) were synthesized as described previously (Pichereau et al., 1997, 1998). [methyl- ${ }^{14} \mathrm{C}$ ]DMSA (2 GBq $\mathrm{mmol}^{-1}$ ) was synthesized as described by Le Berre \& Delacroix (1973), using [methyl- ${ }^{14} \mathrm{C}$ ]mercaptoacetate as a precursor (Isotopchim). [carboxyl- ${ }^{14} \mathrm{C}$ ]DMSA $\left(2 \mathrm{GBq} \mathrm{mmol}^{-1}\right.$ ) was synthesized as described by Maw (1956), using [carboxyl$\left.{ }^{14} \mathrm{C}\right]$ monochloroacetate as a precursor. $\left[\right.$ methyl $\left.-{ }^{14} \mathrm{C}\right] \mathrm{GB}$ $\left(2.04 \mathrm{GBq} \mathrm{mmol}{ }^{-1}\right)$ was prepared enzymically according to Ikuta et al. (1977) by oxidizing radiolabelled choline (NEN). $\left[\right.$ carboxyl $\left.L^{14} \mathrm{C}\right] \mathrm{DMSP}$ was synthesized using the method of Le Berre \& Delacroix (1973) with the modifications described by Pichereau et al. (1998). L- $\left[\right.$ methyl $\left.-{ }^{14} \mathrm{C}\right]$ carnitine $(1.86 \mathrm{GBq}$ $\left.\mathrm{mmol}^{-1}\right)$ was purchased from ICN. D- $\left[\right.$ methyl- $\left.{ }^{14} \mathrm{C}\right]$ carnitine was obtained by biological separation (using Brevibacterium linens) of DL-[methyl $\left.-{ }^{14} \mathrm{C}\right]$ carnitine $(\mathrm{ICN})$ as described by Jebbar et al. (1998).

Uptake and fate of betaines. In the standard uptake assay $(200 \mu \mathrm{l}), 54 \mu \mathrm{M}\left[\right.$ methyl $\left.l^{14} \mathrm{C}\right] \mathrm{GB}\langle(1.85 \mathrm{kBq})$ was added to exponentially growing cells in DM. A sample of $40 \mu \mathrm{l}$ was filtered on GF/F membrane every minute, rinsed twice with isotonic DM and the radioactivity trapped on each filter was determined by liquid scintillation counting (Packard Tri-carb 1600TR). The cell density was adjusted to observe a linear incorporation of radioactivity during a 4 min uptake experiment and ${ }^{14} \mathrm{C}$ incorporation less than $5 \%$ of the supplied radiocarbon. To determine the kinetic parameters of GB uptake, the concentrations of GB were adjusted from 1 to $500 \mu \mathrm{M}$ by adding varied amounts of non-radioactive GB. For the induction assay, the cells were grown in DM and then transferred to DM containing $0.5 \mathrm{M} \mathrm{NaCl}$. Uptake experiments were carried out every $30 \mathrm{~min}$ for $2 \mathrm{~h}$. An assay with chloramphenicol $\left(100 \mu \mathrm{g} \mathrm{ml}^{-1}\right)$ added prior to induction was carried out in parallel. For transport competition assays, nonradioactive competitors were added at a 10 -fold excess into the standard assay medium (competition 1:10). The fate of ${ }^{14} \mathrm{C}$-labelled osmoprotectants was determined as described previously (Pichereau et al., 1998).

Adaptation and challenge conditions. Cultures were grown to an $\mathrm{OD}_{570}$ of 0.6 in $\mathrm{DM}$ and were harvested by centrifugation $(3000 \mathrm{~g}, 10 \mathrm{~min})$. Cells were resuspended in DM prior to adaptation treatment. $\mathrm{NaCl}$ was added to a final concentration of $0.5 \mathrm{M}$ with or without $\mathrm{GB}(1 \mathrm{mM})$ for $1 \mathrm{~h}$. Simultaneously, non-adapted cells were resuspended in fresh DM. After the adaptation period, bacterial cells were pelleted by centrifugation and were challenged with $0.3 \%(\mathrm{w} / \mathrm{v})$ bile salts (sodium cholate/sodium deoxycholate, 1:1) for $30 \mathrm{~s}$ (Flahaut et al., 1996). Viable counts were determined by spreading $1 \mathrm{ml}$ of appropriate dilutions in $0.5 \%(\mathrm{w} / \mathrm{v})$ glucose M17 agar plates (Difco), followed by incubation at $37^{\circ} \mathrm{C}$ for $48 \mathrm{~h}$. Three independent experiments were performed and duplicate platings were carried out for each point. The SD for these experiments did not exceed $9 \%$ of the mean. The ability to enhance the resistance observed for non-adapted cells was expressed as the tolerance factor, i.e. the ratio of the percentage survival of adapted cells to the percentage survival of control cells.
Radioactive pulse labelling, protein extraction and twodimensional electrophoresis. Adapted and non-adapted cells were obtained as described above. The composition of the defined medium used in this experiment was the same as described above, except that methionine and cysteine were omitted. A $1 \mathrm{ml}$ sample of bacterial suspension was supplemented with $10 \mu \mathrm{l}(3.7 \mathrm{GBq})\left[{ }^{35} \mathrm{~S}\right]$ methionine/cysteine Protein Labelling Mix (43.5 TBq mmol ${ }^{-1}$; NEN). After a $15 \mathrm{~min}$ labelling period, $10 \mu \mathrm{l}\left[{ }^{35} \mathrm{~S}\right]$ methionine/cysteine was added again and then repeated twice each $15 \mathrm{~min}$ period. After the labelling period, protein extraction and two-dimensional electrophoresis were performed as described previously (Flahaut et al., 1996). Equal amounts of radioactivity (approx. $10^{6} \mathrm{~d}$.p.m.) were loaded onto the gel in the first dimension (Immobiline Dry Strip pH 4-7, Pharmacia). After electrophoresis in the second dimension, using uniform $14 \%(\mathrm{w} / \mathrm{v})$ SDS-polyacrylamide gel, the gels were dried and exposed to Hyperfilm-MP (Amersham) at $-80^{\circ} \mathrm{C}$ for $6 \mathrm{~d}$ before developing. The spots were quantified by using the program 2 D Analyzer (Biolmage, BI Systems).

\section{RESULTS AND DISCUSSION}

\section{E. faecalis accumulates GB from hypersaline BHI broth}

Enterococci are polyauxotrophic bacteria, routinely cultivated in media supplemented with complex nutrients (e.g. yeast or meat extracts), which potentially contain osmoprotective compounds. Therefore, in our study E. faecalis was inoculated either into rich BHI medium or into chemically defined medium (DM) which lacks compounds known to act as bacterial osmoprotectants. The generation time of $E$. faecalis growing in these media was 35 and $48 \mathrm{~min}$ for BHI and DM, respectively. Therefore, DM is well adapted to satisfy the nutrient requirements of $E$. faecalis and was used in the experiments described below.

The ability to grow in media containing $1.2 \mathrm{M} \mathrm{NaCl}$ $(6.5 \%, \mathrm{w} / \mathrm{v})$ is a major trait that characterizes enterococci (Mundt, 1986). Therefore, the MICs of $\mathrm{NaCl}$ in

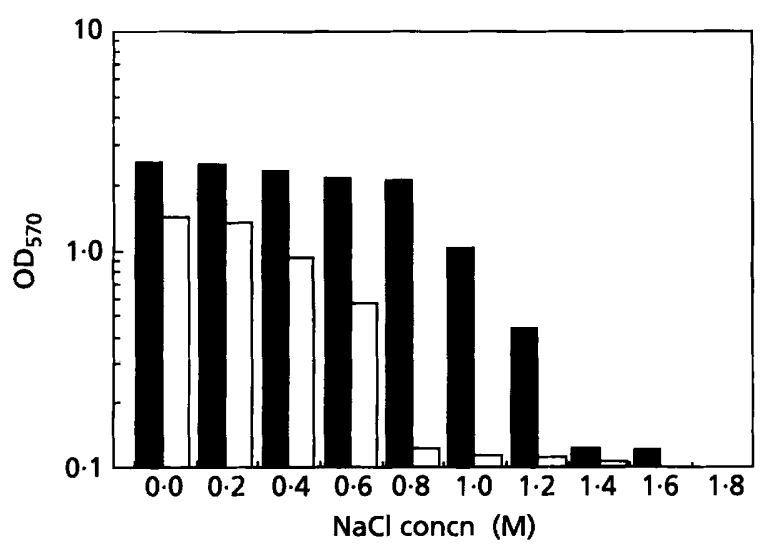

Fig. 1. Influence of the medium on the growth of E. faecalis ATCC 19433 at various $\mathrm{NaCl}$ concentrations. Cultures were grown in $\mathrm{BHI}(\square)$ or in DM $(\square)$. Results are expressed as $O D_{570}$ reached by 16 -h-old cultures. 

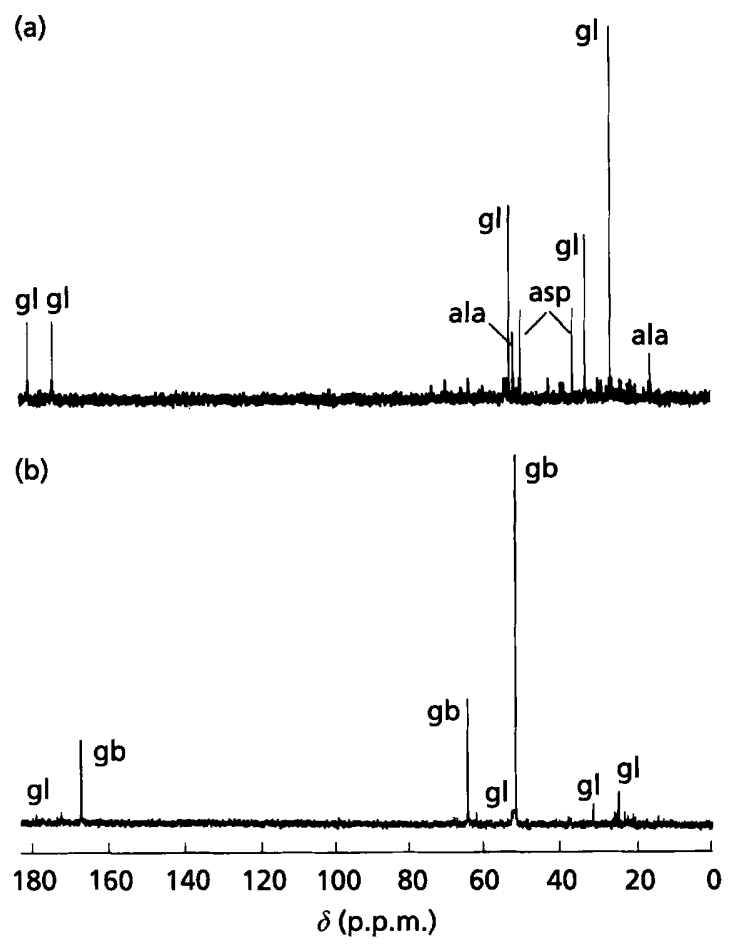

Fig. 2. Natural-abundance ${ }^{13} \mathrm{C}-\mathrm{NMR}$ spectra of ethanolic extracts of $E$. faecalis cells cultivated in $\mathrm{BHI}$ without (a) or with $1.1 \mathrm{M} \mathrm{NaCl}$ (b). Peaks: ala, alanine; asp, aspartate; gl, glutamate; gb, glycine betaine. Spectra were obtained from equivalent amounts of cells (150 $\mathrm{mg}$ protein) so that direct visual comparison can be made.

complex (BHI) and defined (DM) media were determined. They were estimated to be 1.4 and $0.8 \mathrm{M} \mathrm{NaCl}$, respectively, for BHI and DM (Fig. 1). To explain these different MICs, intracellular solutes of salt-stressed cells were extracted and analysed by natural-abundance ${ }^{13} \mathrm{C}$ NMR spectroscopy. The ${ }^{13} \mathrm{C}-\mathrm{NMR}$ spectrum from cells grown in BHI revealed the predominance of the peaks attributable to glutamate, aspartate and alanine (Fig. 2a). In contrast, most of the solutes extracted from saltstressed cells were distributed on the spectrum in three peaks that were all assigned to GB (Fig. 2b). Among the three amino acids detected in the control (Fig. 2a), only glutamate was still detectable (Fig. 2b). Interestingly, spectra obtained from cells cultivated in DM with or without $\mathrm{NaCl}$ showed the presence of as yet unidentified peaks, all different from those of GB (data not shown). Since the complete biosynthesis of GB has not been shown in non-photosynthetic eubacteria and because $\mathrm{GB}$ is not accumulated in $\mathrm{NaCl}$-treated cells of $E$. faecalis grown in DM, we infer that this bacterial species imports and accumulates GB from hyperosmotic BHI broth. These results also demonstrate that previous studies on the $\mathrm{NaCl}$-induced stress response of $E$. faecalis in BHI (Flahaut et al., 1996) were performed under specific conditions in which the osmoprotectant GB was present in the medium and was readily accumulated by stressed cells (Fig. 2b).
Table 1. Effects of osmoprotectants on the growth of $E$. faecalis ATCC 19433 at high osmolarity

\begin{tabular}{|lcc|}
\hline \multirow{2}{*}{$\begin{array}{l}\text { NaCl (M) and osmoprotectant } \\
\text { added to DM culture medium* }\end{array}$} & \multicolumn{2}{c|}{ Growth parameters } \\
\cline { 2 - 3 } & $\boldsymbol{\mu}\left(\mathbf{h}^{-1}\right)$ & OD $_{570}$ \\
\hline 0+ no osmoprotectant & $1 \cdot 25$ & $1 \cdot 60$ \\
0.75+ no osmoprotectant & $0 \cdot 13$ & $0 \cdot 25$ \\
0+ GB & $0 \cdot 84$ & $1 \cdot 36$ \\
0+ AsB & $0 \cdot 81$ & $1 \cdot 39$ \\
0+DMSA & $0 \cdot 71$ & $1 \cdot 15$ \\
0+DMSP & $0 \cdot 68$ & $1 \cdot 17$ \\
0+BB & $0 \cdot 74$ & $1 \cdot 28$ \\
0+ L-Car & $0 \cdot 84$ & $1 \cdot 40$ \\
0+D-Car & $0 \cdot 89$ & $1 \cdot 31$ \\
0+DMG & $0 \cdot 59$ & $1 \cdot 10$ \\
0+Ect & $0 \cdot 13$ & $0 \cdot 26$ \\
0+Pip & $0 \cdot 13$ & $0 \cdot 26$ \\
0+Pro & $0 \cdot 18$ & $0 \cdot 28$ \\
\hline
\end{tabular}

* Each putative osmoprotectant was added to the culture medium at a final concentration of $1 \mathrm{mM}$. L- and D-Car, L- and Dcarnitine; Ect, ectoine; Pip, pipecolate; Pro, proline.

t Growth parameters are expressed as growth rate $\langle\mu\rangle$ and maximal $\mathrm{OD}_{\mathbf{5 7 0}}$ reached by the cultures in the stationary phase of growth. Each value is the mean of triplicate values (SD did not exceed $10 \%$ of the mean).

\section{GB and its structural analogues, but not other osmoprotectants tested, relieve the inhibition of growth in $E$. faecalis by salt}

Bacteria were grown in osmoprotectant-free DM with or without $0.75 \mathrm{M} \mathrm{NaCl}$. Under hyperosmotic conditions the growth of $E$. faecalis was greatly reduced (the growth rate, $\mu$, decreased from $1.25 \mathrm{~h}^{-1}$ in control cells to $0 \cdot 13 \mathrm{~h}^{-1}$ in stressed cells) (Table 1 ). Various molecules known to act as osmoprotectants for Escherichia coli and other bacteria, i.e. betaines (quaternary ammonium compounds) and their sulfonio and arsonio analogues, and the imino acids ectoine, proline and pipecolate were assayed. Under our experimental conditions, these compounds had no significant effect on bacterial growth in the defined medium without added $\mathrm{NaCl}$ (data not shown).

The addition of $1 \mathrm{mM}$ GB to DM containing $0.75 \mathrm{M}$ $\mathrm{NaCl}$ reduced the doubling time of the cells from $7 \cdot 7$ to $1 \cdot 2 \mathrm{~h}$ and increased the growth yield 5.4-fold (Table 1 , Fig. 3). Thus, GB was highly osmoprotective for $E$. faecalis. This result was expected because GB which is taken up from BHI broth allowed bacterial cells to cope with elevated salt concentrations (Fig. 1, Fig. 2b). A similar growth improvement was observed with other MOCs, i.e. AsB, DMSA, DMSP, $\gamma$-butyrobetaine (BB) or carnitine (in a non-enantiospecific manner, since $\mathrm{L}$ - and D-carnitine equally restored the growth of stressed cells) (Table 1). Dimethylglycine (DMG) also effected growth restoration of salt-stressed cultures of E. faecalis, but to a minor extent compared to the growth recovery induced 


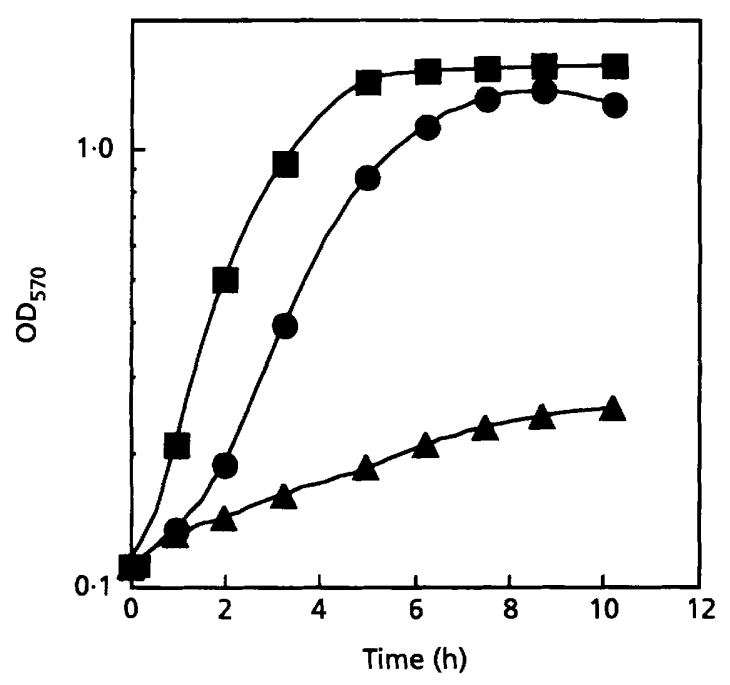

Fig. 3. Effects of GB on salt-stressed cultures of $E$. faecalis ATCC 19433. Cells were cultivated in DM ( $\boldsymbol{G}$, control), DM containing $0.75 \mathrm{M} \mathrm{NaCl}(\Delta)$ or DM containing $0.75 \mathrm{M} \mathrm{NaCl}$ and $1 \mathrm{mM} \mathrm{GB}$ (०).

by GB and its structural analogues. On the other hand, proline, ectoine and pipecolate did not display any osmoprotective effect for salt-stressed cells. In all, our results demonstrate that in E. faecalis, exogenously supplied compounds ensuring osmoprotection are restricted to the betaines and their analogues. In contrast, most of the bacteria studied so far accept both betaines and imino acids such as proline, pipecolate or ectoine as effective osmoprotectants (Csonka \& Hanson, 1991; Gouesbet et al., 1994; Gutierrez et al., 1995; Jebbar et al., 1997).

\section{Accumulation and uptake characteristics of GB and its derivatives}

Accumulation characteristics of betaines and their analogues were determined in bacterial cells grown under salt stress $(0.5 \mathrm{M} \mathrm{NaCl})$ in the presence of the corresponding radioactive compounds. Accumulation levels of GB, DMSA, DMSP and D- and L-carnitine were roughly equivalent, ranging from 1.3 to $1.5 \mu \mathrm{mol}(\mathrm{mg}$ protein $)^{-1}$. Moreover, all the radioactivity was recovered in the supplied molecule, indicating that these osmoprotectants are accumulated and not catabolized by $E$. faecalis. Osmoprotection by carnitine has already been demonstrated in other bacteria including Escherichia coli, Lactobacillus plantarum, Listeria monocytogenes and B. linens (Kets et al., 1994; Ko et al., 1994; Verheul et al., 1997; Jebbar et al., 1998). In the latter species, carnitine acts as an osmoprotectant in an enantiospecific manner. Indeed, D-carnitine is accumulated by osmoregulating cells of $B$. linens, whereas L-carnitine is transformed into GB (Jebbar et al., 1998). We demonstrate here that both $\mathrm{D}$ - and L-carnitine were equally osmoprotective in E. faecalis and were accumulated without metabolism into GB.

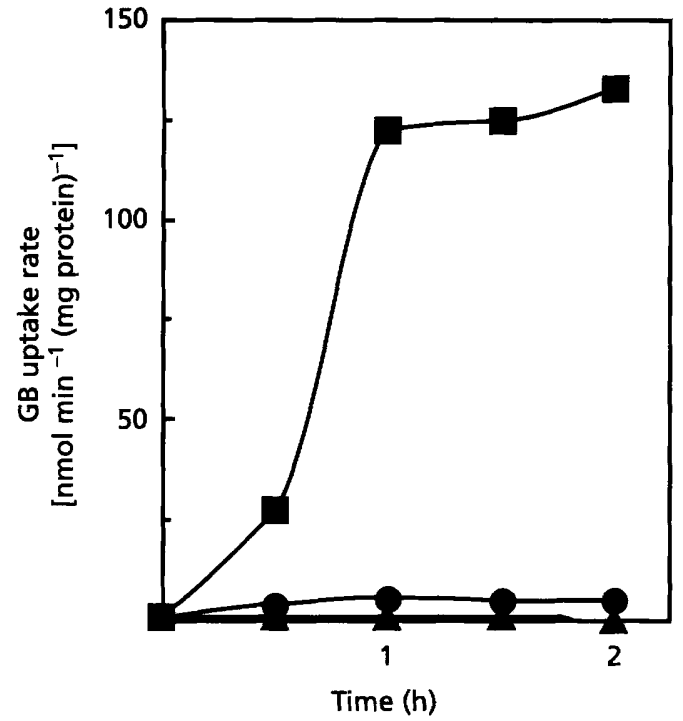

Fig. 4. Induction of GB uptake in E. faecalis ATCC 19433 by $\mathrm{NaCl}$. Cells cultivated in control DM were transferred into DM (A), DM containing $0.5 \mathrm{M} \mathrm{NaCl}(\boldsymbol{C})$ or DM containing $0.5 \mathrm{M}$ $\mathrm{NaCl}$ and $100 \mu \mathrm{g}$ chloramphenicol ml $\mathrm{ml}^{-1}$ (O). Each point is the mean of three independent uptake assays (SD did not exceed $12 \%$ of the mean).

Kinetic parameters of GB uptake by E. faecalis were also examined. Determination of $K_{\mathrm{m}}$ revealed the presence of a high affinity uptake activity for $\mathrm{GB}\left(K_{\mathrm{m}}=3.3 \mu \mathrm{M}\right)$. The GB uptake velocities of cells cultivated in DM with or without $0.5 \mathrm{M} \mathrm{NaCl}$ were substantially different [130 and $0.3 \mathrm{nmol} \min ^{-1}$ (mg protein $)^{-1}$, respectively]. The activity of GB uptake system(s) was stimulated by salt concentration in the growth medium, suggesting saltinduction of the GB uptake system(s) in E. faecalis. The putative salt-induction of GB uptake was determined after transferring the cells from DM lacking $\mathrm{NaCl}$ into hypersaline medium $(0.5 \mathrm{M} \mathrm{NaCl})$. One hour after the salt shock, GB uptake was enhanced 400 -fold (Fig. 4) in cells which were incubated without chloramphenicol, but barely increased in cells that were incubated with chloramphenicol (Fig. 4).

Competition assays were performed to determine the substrate specificity of GB uptake. As expected, all the $\mathrm{GB}$ analogues inhibited $\left[{ }^{14} \mathrm{C}\right] \mathrm{GB}$ uptake. In spite of its weak osmoprotective effect on salt-stressed cultures of E. faecalis, DMG was an inhibitor of GB uptake $(52 \%$ inhibition of GB uptake when DMG was supplied at a 10 -fold excess over radiolabelled GB). Moreover, the other MOCs inhibited GB uptake by $30-46 \%$. In contrast, none of the compounds that were not osmoprotective for E. faecalis (pipecolate, ectoine and proline) competed with GB transport.

High-affinity betaine porters occur in a large variety of Gram-positive bacteria. In particular, such activity has been shown in Lactobacillus acidophilus (Hutkins et al., 1987), Bacillus subtilis (Jebbar et al., 1997), Staphylococcus aureus (Pourkomailan \& Booth, 1992; Stimeling 


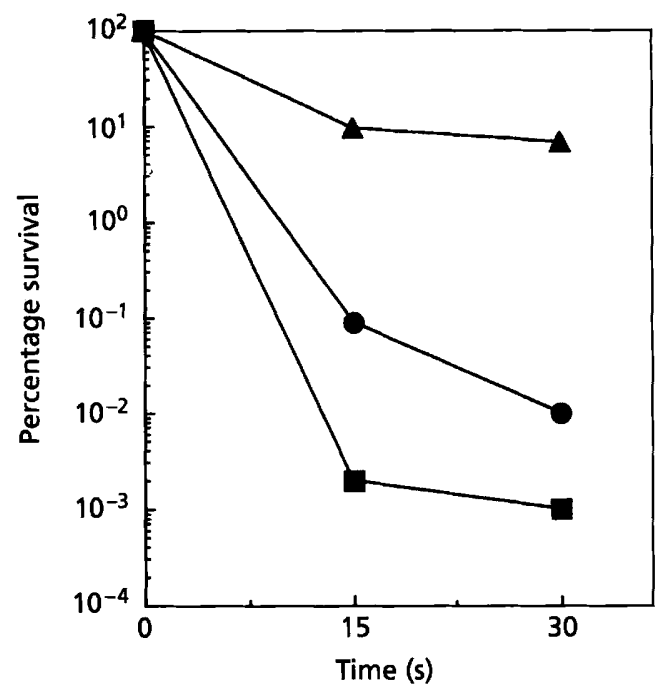

Fig. 5. Effect of GB on salt-induced cross-protection against bile salts in E. faecalis ATCC 19433. After a $1 \mathrm{~h}$ adaptation period in which cells were incubated in DM (D), DM containing $0.5 \mathrm{M}$ $\mathrm{NaCl}(\boldsymbol{A})$ or DM containing $0.5 \mathrm{M} \mathrm{NaCl}$ and $1 \mathrm{mM} \mathrm{GB}$ (O), cells were subjected to a $0.3 \%$ bile salts challenge.

et al., 1994), Corynebacterium glutamicum (Peter et al., 1996, 1997) and L. monocytogenes (Patchett et al., 1994; Verheul et al., 1997). In contrast to the situation observed in Escherichia coli, which transports GB through two general osmoporters (ProU and ProP, both of which accept all of the osmoprotectants assayed so far in this species) (Gouesbet et al., 1994), the high-affinity GB uptake systems of these Gram-positive bacteria display high structural specificity which, as observed in E. faecalis, do not accept proline or ectoine as substrates.

\section{Influence of GB on salt-induced cross-tolerance in $E$. faecalis}

Salt-induced cross-tolerance to lethal treatments have been characterized in E. faecalis cultivated in $\mathrm{BHI}$ rich medium (Flahaut et al., 1996). The results emphasized the ability of $\mathrm{NaCl}$-stressed bacteria to enhance resistance against challenges such as ethanol, hydrogen peroxide, heat and detergents (SDS and bile salts). The maximal induced resistance (adaptation factor of 500) was observed when cells were subjected to a moderate salt stress $(1.2 \mathrm{M} \mathrm{NaCl})$ followed by a lethal treatment with bile salts $(0 \cdot 3 \%, \mathrm{w} / \mathrm{v})$. Because $\mathrm{BHI}$ contains $\mathrm{GB}$, the specific effects of this osmoprotectant in tolerance acquisition remained unknown. To determine whether GB was implicated in this phenomenon, the adaptation pretreatment in this study was achieved in osmoprotectant-free DM with or without added GB and the cells subsequently subjected to the same lethal bile salts treatment. Preincubation of cells in DM containing $0.5 \mathrm{M} \mathrm{NaCl}$ (a concentration that moderately reduces bacterial growth) triggered an impressive cross-tolerance against bile salts challenge, with tolerance factors of 4850 and 6800 after 15 and $30 \mathrm{~s}$, respectively (Fig. 5). When GB was added to the adaptation medium, cellular survival was only 45 - and 10-fold higher than the control after 15 and $30 \mathrm{~s}$, respectively. Similar results were obtained when DMSA was used in place of GB. These results demonstrate that the presence of an osmoprotectant during the adaptation period decreased the ability of $E$. faecalis to take advantage of a salt constraint and therefore to adapt to lethal challenge. Thus, although GB efficiently protects salt-stressed cells of $E$. faecalis, the intracellular accumulation of this compound appears to alter the part of the osmoadaptive response that induces cross-tolerance.

\section{Does $\mathrm{GB}$ interfere with the synthesis of $\mathrm{NaCl}$-induced stress proteins?}

We sought to determine whether GB has an effect on the induction of the stress proteins which are amplified after salt-shock in E. faecalis (Flahaut et al., 1996). We used two-dimensional electrophoresis to study the protein profiles of E. faecalis cells cultivated in DM with or without $0.5 \mathrm{M} \mathrm{NaCl}$, in the presence or absence of GB. The $0.5 \mathrm{M} \mathrm{NaCl}$ upshock induced the synthesis of 13 polypeptides (Fig. 6b). The relative induction ratios of four of them (spots 1, 2, 4 and 6) increased to at least eightfold higher levels than the corresponding controls (Fig. 6a, b). The presence of GB decreased production of most of the $\mathrm{NaCl}$-induced stress proteins (Fig. 6c). This finding suggests that osmoprotectants interfere, directly or indirectly, with the program of gene expression in response to salt stress in E. faecalis. A related observation was reported in salt-stressed animal cells by Petronini et al. (1993), who demonstrated the inhibition of the synthesis of the heat-shock protein HSP70 by exogenously provided GB. However, the relative rate of synthesis of two salt-induced proteins (spots 6 and 8) remained in the presence of GB. Considering the previous results, these polypeptides should not be sufficient to acquire cross-adaptation. They should be specifically implied in salt-stress adaptation of E. faecalis rather than in general stress protection. Similarly, in $S$. aureus, whereas the synthesis of 10 proteins increased in response to $\mathrm{NaCl}$ stress, the presence of $\mathrm{GB}$ during hyperosmotic shock only decreased the production of one of them (Vijaranakul et al., 1997).

While GB is a beneficial molecule to organisms subjected to hyperosmotic stressful conditions, we show here that it has a negative effect on bacterial stress adaptation. A similar response was recently reported in Salmonella, in which GB reduced high-salinity-dependent cross-protection against heat stress (Fletcher \& Csonka, 1998). Of particular interest is the fact that osmoprotectants occur widely in natural environments (Blunden \& Gordon, 1986; Anthoni et al., 1991). In such media bacterial cells are often subjected to multiple stresses and the presence of GB or other osmoprotectants could prevent the induction of adaptation mechanisms in bacterial cells. Consequently, our results raise questions about the actual beneficial effects of GB and other osmo- 
(a)

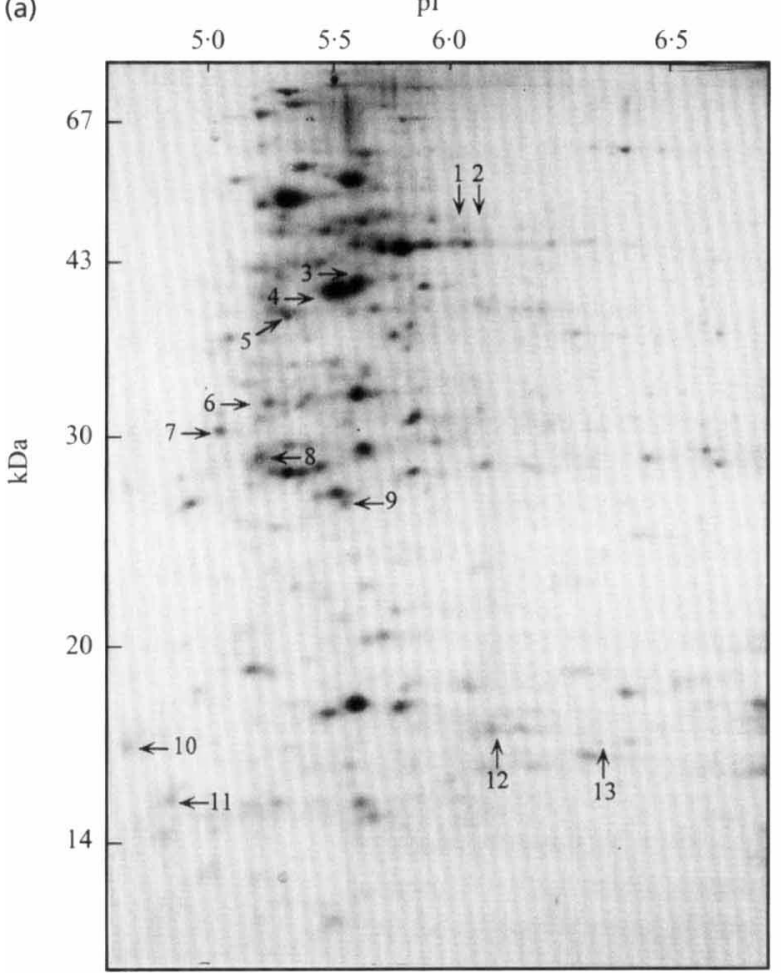

(c)

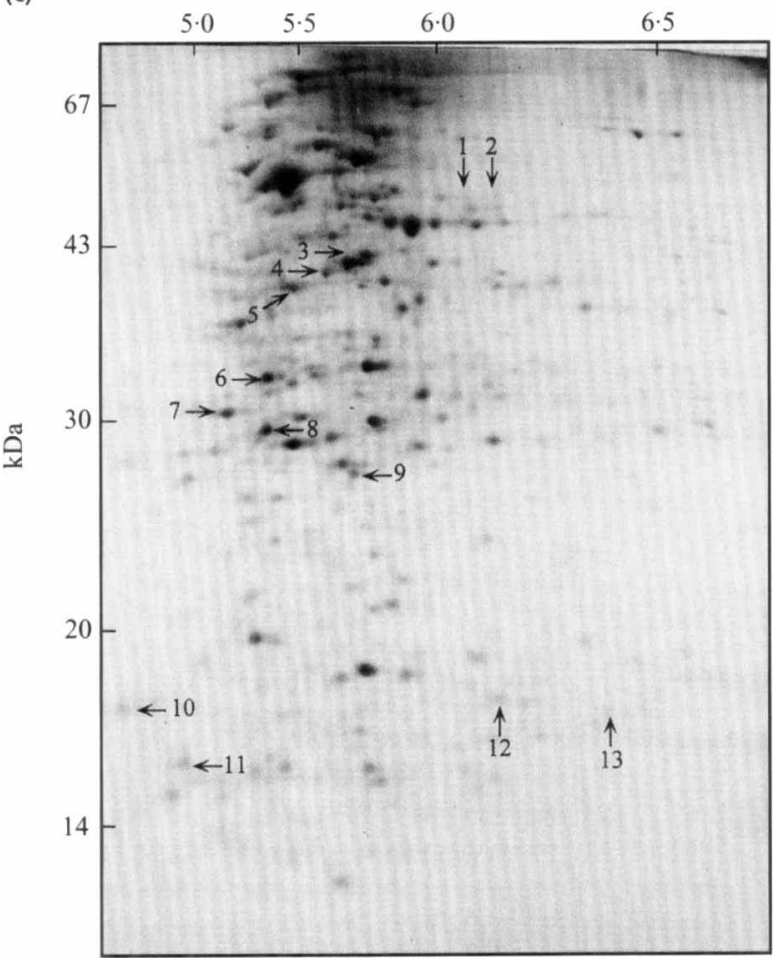

(b)

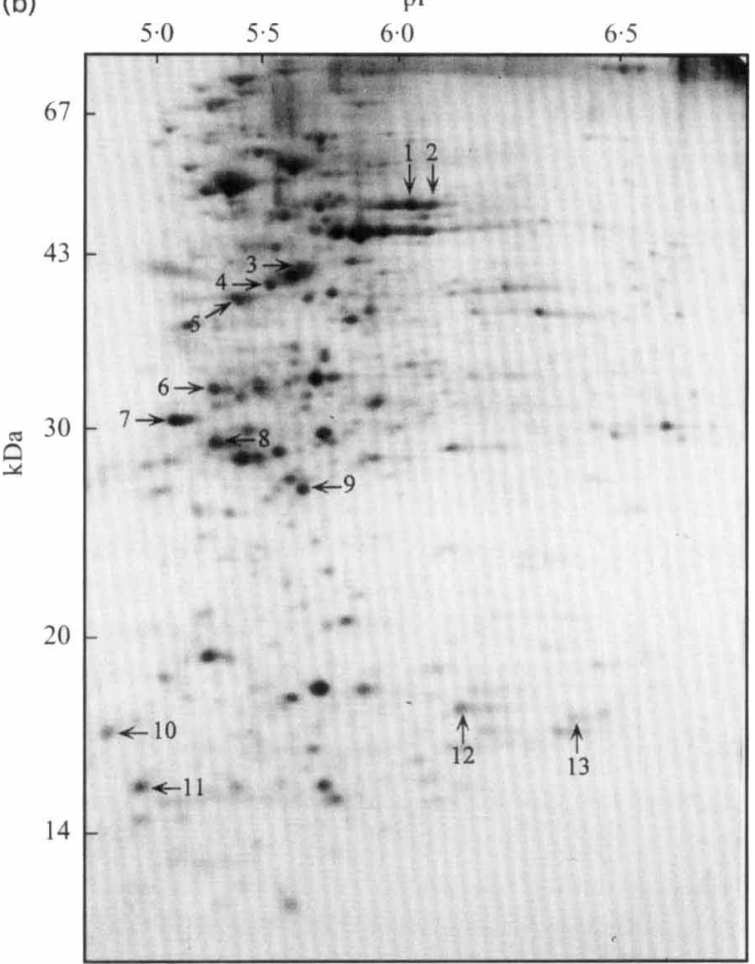

protectants on bacterial survival and proliferation in natural environments.

\section{ACKNOWLEDGEMENTS}

This research was supported by grants from the Centre National de la Recherche Scientifique (DSV), the Direction de
Fig. 6. Two-dimensional gel analysis of protein extracts from $E$. faecalis ATCC 19433 cells exposed to $0.5 \mathrm{M} \mathrm{NaCl}$ shock (b) or $\mathrm{NaCl}$ pretreatment with $1 \mathrm{mM} \mathrm{GB}$ (c) and from control cells (a). Cells were treated for $1 \mathrm{~h}$ and labelled with $\left[{ }^{35} \mathrm{~S}\right]$ methionine/cysteine during this period. Extracts were prepared as described in Methods. la Recherche et des Etudes Doctorales. Jérôme Paillard is greatly acknowledged for helpful technical assistance and Louis Communier for his help in the preparation of photographic illustrations. 


\section{REFERENCES}

Amezaga, M.-R., Davidson, I., McLaggan, D., Verheul, A., Abee, T. \& Booth, I. R. (1995). The role of peptide metabolism in the growth of Listeria monocytogenes ATCC 23074 at high osmolarity. Microbiology 141, 41-49.

Anthoni, U., Christophersen, C., Hougaard, L. \& Nielsen, P. H. (1991). Quaternary ammonium compounds in the biosphere - an example of a versatile adaptive strategy. Comp Biochem Physiol 99B, 1-18.

Bernard, T., Pocard, J.-A., Perroud, B. \& Le Rudulier, D. (1986). Variations in the response of salt-stressed Rbizobium strains to betaines. Arch Microbiol 143, 359-364.

Blunden, G. \& Gordon, S. (1986). Betaines and their sulphonio analogues in marine algae. Prog Phycol Res 4, 39-80.

Brown, A. D. (1976). Microbial water stress. Bacteriol Rev 40, 803-846.

Csonka, L. N. \& Epstein, W. (1996). Osmoregulation. In Escherichia coli and Salmonella: Cellular and Molecular Biology, pp. 1210-1223. Edited by F. C. Neidhardt, R. Curtiss, J. L. Ingraham, E. C. C. Lin, K. Brooks Low, B. Magasanik, W. S. Reznikoff, M. Riley, M. Schaechter \& H. E. Umbarger. Washington, DC: American Society for Microbiology.

Csonka, L. N. \& Hanson, A. D. (1991). Prokaryotic osmoregulation: genetics and physiology. Annu Rev Microbiol 45, 569-606.

Flahaut, S., Benachour, A., Giard, J. C., Boutibonnes, P. \& Auffray, Y. (1996). Defense against lethal treatments and de novo protein synthesis induced by $\mathrm{NaCl}$ in Enterococcus faecalis ATCC 19433. Arch Microbiol 165, 317-324.

Flahaut, S., Boutibonnes, P. \& Auffray, Y. (1997). Enterococci in the human environment. Can J Microbiol 43, 699-708.

Fletcher, S. A. \& Csonka, L. N. (1998). Characterization of the induction of increased thermotolerance by high osmolarity in Salmonella. Food Microbiol 15, 307-317.

Godfree, A. F., Kay, D. \& Wyer, M. D. (1997). Faecal streptococci as indicators of faecal contamination in water. Soc Appl Bacteriol Symp Ser 26, 110S-119S.

Gouesbet, G., Jebbar, M., Talibart, R., Bernard, T. \& Blanco, C. (1994). Pipecolic acid is an osmoprotectant for Escherichia coli taken up by the general osmoporters ProU and ProP. Microbiology 140, 2415-2422.

Gutierrez, C., Abee, T. \& Booth, I. R. (1995). Physiology of the osmotic stress response in microorganisms. Int J Food Microbiol 28, 233-244.

Hecker, M., Heim, C., Völker, U. \& Wölfel, L. (1988). Induction of stress proteins by sodium chloride treatment in Bacillus subtilis. Arch Microbiol 150, 564-566.

Hecker, M. \& Völker, U. (1990). General stress proteins in Bacillus subtilis. FEMS Microbiol Ecol 74, 214.

Hutkins, R. W., Ellefson, W. L. \& Kashket, E. R. (1987). Betaine transport imparts osmotolerance on a strain of Lactobacillus acidopbilus. Appl Environ Microbiol 53, 2275-2281.

Ikuta, S., Matuura, K., Imamura, S., Misaki, H. \& Horiuti, Y. (1977). Oxidative pathway of choline to betaine in the soluble fraction prepared from Arthrobacter globiformis. J Biochem 82, 157-163.

Jebbar, M., Talibart, R., Gloux, K., Bernard, T. \& Blanco, C. (1992). Osmoprotection of Escherichia coli by ectoine: uptake and accumulation characteristics. J Bacteriol 174, 5027-5035.

Jebbar, M., von Blohn, C. \& Bremer, E. (1997). Ectoine functions as an osmoprotectant in Bacillus subtilis and is accumulated via the ABC-transport system OpuC. FEMS Microbiol Lett 154, $325-330$.

Jebbar, M., Champion, C., Blanco, C. \& Bonnassie, S. (1998). Carnitine acts as a compatible solute in Brevibacterium linens. Res Microbiol 149, 211-219.

Kets, E. P. W., Galinski, E. A. \& De Bont, J. A. M. (1994). Carnitine: a novel compatible solute in Lactobacillus plantarum. Arch Microbiol 162, 243-248.

Ko, R., Smith, L. T. \& Smith, G. M. (1994). Glycine betaine confers enhanced osmotolerance and cryotolerance on Listeria monocytogenes. J Bacteriol 176, 426-431.

Kunin, C. M. \& Rudy, J. (1991). Effect of $\mathrm{NaCl}$-induced osmotic stress on intracellular concentrations of glycine betaine and potassium in Escherichia coli, Enterococcus faecalis, and staphylococci. J Lab Clin Med 118, 217-224.

Le Berre, A. \& Delacroix, A. (1973). L'addition des sels d'amine tertiaires aux composés éthyléniques électrophiles. III. Bétaïnes et sels quaternaires à partir d'acides $\alpha, \beta$-insaturés. Bull Soc Chim $\mathrm{Fr}$ 7/8, 2404-2408.

Le Rudulier, D., Strøm, A. R., Dandekar, A. M., Smith, L. T. \& Valentine, R. C. (1984). Molecular biology of osmoregulation. Science 224, 1064-1068.

Lucht, J. M. \& Bremer, E. (1994). Adaptation of Escherichia coli to high osmolarity environments: osmoregulation of the highaffinity glycine betaine transport system ProU. FEMS Microbiol Rev 14, 3-20.

Maw, G. A. (1956). Thetin-homocysteine transmethylase. A preliminary manometric study of the enzyme from rat liver. Biochem J 63, 116-124.

Measures, J. C. (1975). Role of amino acids in osmoregulation of nonhalophilic bacteria. Nature 257, 398-400.

Mundt, J. O. (1986). Enterococci. In Bergey's Manual of Determinative Bacteriology, pp. 1063-1065. Edited by P. H. A Sneath, N. S. Mair \& J. G. Holt. Baltimore: Williams \& Wilkins.

Patchett, R. A., Kelly, A. F. \& Kroll, R. G. (1994). Transport of glycine-betaine by Listeria monocytogenes. Arch Microbiol 162, 205-210.

Peddie, B. A., Chambers, S. T. \& Lever, M. (1996). Is the ability of urinary tract pathogens to accumulate glycine betaine a factor in the virulence of pathogenic strains? J Lab Clin Med 128, 417-422.

Peter, H., Burkovski, A. \& Krămer, R. (1996). Isolation, characterization, and expression of the Corynebacterium glutamicum bet $P$ gene, encoding the transport system for the compatible solute glycine betaine. J Bacteriol 178, 5229-5234.

Peter, H., Bader, A., Burkovski, A., Lambert, C. \& Krämer, R. (1997). Isolation of the putP gene of Corynebacterium glutamicum and characterization of a low-affinity uptake system for compatible solutes. Arch Microbiol 168, 143-151.

Petronini, P. G., De Angelis, E. M., Borghetti, A. F. \& Wheeler, K. P. (1993). Effect of betaine on HSP70 expression and cell survival during adaptation to osmotic stress. Biochem $J 293$, 553-558.

Pichereau, V., Cosquer, A., Gaumont, A. C. \& Bernard, T. (1997). Synthesis of trimethylated phosphonium and arsonium analogues of the osmoprotectant glycine betaine; contrasted biological activities in two bacterial species. Bioorg Med Chem Lett 7 , 2893-2896.

Pichereau, V., Pocard, J.-A., Hamelin, J., Blanco, C. \& Bernard, T. (1998). Differential effects of dimethylsulfoniopropionate, dimethylsulfonioacetate, and other S-methylated compounds on the growth of Sinorbizobium meliloti at low and high osmolarities. Appl Environ Microbiol 64, 1420-1429. 
Pourkomailian, B. \& Booth, I. R. (1992). Glycine betaine transport by Staphylococcus aureus evidence for two transport systems and for their possible roles in osmoregulation. J Gen Microbiol 138, 2515-2518.

Smith, L. T. (1996). Role of osmolytes in adaptation of osmotically stressed and chill-stressed Listeria monocytogenes grown in liquid media and on processed meat surfaces. Appl Environ Microbiol 62, 3088-3093.

Stimeling, K. W., Graham, J. E., Kaenjak, A. \& Wilkinson, B. J. (1994). Evidence for feedback (trans) regulation of, and two systems for, glycine betaine transport by Staphylococcus aureus. Microbiology 140, 3139-3144.

Tesone, S., Hughes, A. \& Hurst, A. (1981). Salt extends the upper temperature limit for growth of food-poisoning bacteria. Can J Microbiol 27, 970-972.
Verheul, A., Glaasker, E., Poolman, B. \& Abee, T. (1997). Betaine and $\mathrm{L}$-carnitine transport by Listeria monocytogenes $\mathrm{Scott} \mathrm{A}$ in response to osmotic signals. J Bacteriol 179, 6979-6985.

Vijaranakul, U., Nadakavukaren, M. J., Bayles, D. O., Wilkinson, B. J. \& Jayaswal, R. K. (1997). Characterization of an $\mathrm{NaCl}$ sensitive Staphylococcus aureus mutant and rescue of the $\mathrm{NaCl}$ sensitive phenotype by glycine betaine but not by other compatible solutes. Appl Environ Microbiol 63, 1889-1897.

Völker, U., Mach, H., Schmid, R. \& Hecker, H. (1992). Stress proteins and cross-protection by heat shock and salt stress in Bacillus subtilis. J Gen Microbiol 138, 2125-2135.

Received 3 July 1998; revised 14 October 1998; accepted 22 October 1998. 